\title{
A Pharmacokinetic and Dosing Study of Intravenous Insulin-Like Growth Factor-I and IGF-Binding Protein-3 Complex to Preterm Infants
}

\author{
CHATARINA LÖFQVIST, AIMON NIKLASSON, EVA ENGSTRÖM, LENA E. FRIBERG, CECILIA CAMACHO-HÜBNER, \\ DAVID LEY, JAN BORG, LOIS E. H. SMITH, AND ANN HELLSTRÖM
}

\begin{abstract}
Department of Ophthalmology [C.L., A.H.]; Department of Pediatrics [A.N., E.E.], Sahlgrenska Academy at Gothenburg University, Göteborg 416 85, Sweden; Department of Pharmaceutical Biosciences [L.E.F.], Uppsala University, Uppsala 751 05, Sweden; Department of Woman and Child Health [C.C.-H.], Karolinska Institutet, 17176 Stockholm, Sweden; Department of Pediatrics [D.L.], Lund University, Lund 221 84, Sweden; Premacure AB [J.B.], Uppsala Science Park, Uppsala 751 83, Sweden; Department of Ophthalmology [L.E.H.S.], Harvard Medical School, Boston, Massachusetts 02115
\end{abstract}

\begin{abstract}
In preterm infants, low levels of Insulin like growth factor 1 (IGF-I) have been associated with impaired growth and retinopathy of prematurity. Our objective was to study safety and pharmacokinetics of i.v. administered rhIGF-I with its binding protein 3 (rhIGFBP-3) to preterm infants. At 3 d chronological age, an i.v. $3 \mathrm{~h}$ infusion of rhIGF-I/rhIGFBP-3 was administered followed by serial measurements of IGF-I and IGFBP-3. Infants were evaluated for physiologic safety measurements. The individual dose of rhIGF-I ranged from 1 to $12 \mu \mathrm{g} / \mathrm{kg}$. The study was conducted at Queen Silvia Children's Hospital, Gothenburg, Sweden, between January and November 2007. Five patients (3 F) with mean (range) post menstrual age $27 \mathrm{wk}(26-29)$ and birth weight $1022 \mathrm{~g}$ (810-1310) participated. IGF-I and IGFBP-3 levels before infusion were median (range) 18 (12-28) and 771 (651-1047) ng/mL, respectively. Immediately after study drug infusion, serum IGF-I and IGFBP-3 levels were 38 (25-59) and 838 (754-1182) ng/mL, respectively. Median (range) half-life for IGF-I and IGFBP-3 was $0.79(0.59-1.42)$ and 0.87 (0.85-0.94) hours, respectively. Blood glucose, insulin, sodium, potassium, and physiologic safety measures were within normal ranges. The rhIGF-I/rhIGFBP-3 equimolar proportion was effective in increasing serum IGF-I levels and administration under these study conditions was safe and well tolerated. (Pediatr Res 65: 574-579, 2009)
\end{abstract}

$I^{\infty}$ GF-1 plays a central role in regulating fetal growth, particularly in the third trimester as demonstrated by experimental studies (1), which seems to be the case in humans as well, as demonstrated with patients with IGF-I gene defects $(2,3)$. In addition, IGF-I has been shown to play important roles in the intrauterine development of the $\mathrm{CNS}$ and the vasculature $(2,3)$. IGF-I promotes proliferation, maturation, and differentiation of neural stem cells and of neuronal and oligodendro-

Received August 25, 2008; accepted December 21, 2008.

Correspondence: Ann Hellström, M.D., Ph.D., Section of Pediatric Ophthalmology, The Queen Silvia Children's Hospital, The Sahlgrenska Academy at Gothenburg University, S-416 85 Göteborg, Sweden; e-mail: ann.hellstrom@medfak.gu.se

Supported by the Swedish Medical Research Council (7905, 10863, and 13515) and The Göteborg Medical Society. Lois Smith is grateful for support from the V. Kann Rasmussen Foundation, National Eye Institute Grants EY008670 and EY14811, and Children's Hospital Boston Mental Retardation and Developmental Disabilities Research Center Grant P01 HD18655. cyte precursors (4). IGF-I has also been shown to play an important role in retinal vascularization, both physiologic and pathologic, in both experimental and clinical studies $(2,5)$.

The bioavailability of IGF-I is regulated by several binding proteins. IGF binding protein 3 (IGFBP-3) is the predominant binding protein in the blood circulation. Normally, virtually all the IGF-I/IGFBP-3 is in a ternary complex with their binding to the acid-labile subunit (ALS) (6) and are protected from protease activity. In preterm children (born $<32$ gestational weeks), we have earlier found very low serum levels of ALS during the first weeks of life (data not published). The dissociation of IGF-I and IGFBP-3 is controlled by proteases, which regulate tissue availability of bioactive free IGF-I, which can then bind to cellular IGF-receptors (6). IGFBP-3 can modulate cellular mechanisms independently of IGF-I, and we have earlier shown that IGFBP-3 promotes vascular regrowth in experimentally induced retinopathy (7).

Serum concentrations of both IGF-I and IGFBP-3 fall rapidly, below in utero levels, after preterm birth (8). IGF-I levels in fetal serum rise in the third trimester and are positively correlated with gestational age and birth weight $(9,10)$. Thus, in general, the more premature the infant, the lower is the level of serum IGF-1 at birth.

In preterm infants, low serum levels of IGF-I have been associated with slow weight gain and slow head (brain) growth as well as with the later development of retinopathy of prematurity $(5,11,12)$. The aim of our study was to evaluate the safety and pharmacokinetic parameters of a 3-h infusion of rhIGF-I/rhIGFBP-3-glucose to five very preterm infants and to determine the dose of rhIGF-I required bringing IGF-I into the physiologic range, defined as the in utero levels for corresponding GA $(20-60 \mu \mathrm{g} / \mathrm{L})(13)$.

\section{MATERIALS AND METHODS}

Study subjects. A total of five infants were recruited to the study, which was conducted in the neonatal ward at Queen Silvia Children's Hospital in

\footnotetext{
Abbreviations: ALS, acid-labile subunit; CL, clearence; FFP, fresh frozen plasma; GHIS, growth hormone insensitivity syndrome; IGFBP-3, insulin like growth factor binding protein 3
} 
Table 1. Baseline characteristics of infants with single dose of rhIGF-I/rhIGFBP-3 infusion

\begin{tabular}{|c|c|c|c|c|}
\hline Characteristics (gender) & GA at birth $(w k+d)$ & Birth weight (g/SDS) & Parity & Serum IGF-I day $2(\mu \mathrm{g} / \mathrm{L})$ \\
\hline Girl & $26+5$ & $935 /-0.578$ & 1 & 5 \\
\hline Boy & $29+1$ & $1310 /-0.771$ & 1(3) & 22 \\
\hline Boy & $26+0$ & $860 /-0.682$ & 1 & 11 \\
\hline Girl & $28+5$ & $1195 /-0.756$ & 1 & 14 \\
\hline Girl & $26+0$ & $810 /-0.822$ & $1(2)$ & 17 \\
\hline
\end{tabular}

Gothenburg, Sweden, between January 2007 and November 2007. Inclusion criteria were a gestational age (GA) at birth between $26 \mathrm{wk}+0 \mathrm{~d}$ and $29 \mathrm{wk}$ $+6 \mathrm{~d}$ (GA estimated by ultrasound in pregnancy week 17), a birth weight $>-2$ SD and $<+2$ SD based on $z$ score for age and sex and a serum IGF-I concentration measured at postnatal day 2 below $25 \mu \mathrm{g} / \mathrm{L}$.

The children were enrolled during their first day of life. Exclusion criteria were severe sepsis, gross malformation (including cardiac abnormalities other than PDA), known or suspected chromosomal abnormality, genetic disorder or syndrome according to the investigator's opinion, IGF-I level $\geq 25 \mu \mathrm{g} / \mathrm{L}$ at study day 2 (to minimize the risk of un-physiologically high IGF-I levels), plasma glucose level $<2.5 \mathrm{mM}$ or $>10 \mathrm{mM}$ at study day 2 , and administration of plasma later than $24 \mathrm{~h}$ after birth.

The five patients (three females and two males) had a mean gestational age of $27 \mathrm{wk}$ and a mean birth weight of $1022 \mathrm{~g}$. Clinical characteristics of the five infants are given in Table 1 . One girl had a serum IGF-I on study day $3 \geq 25$ $\mu \mathrm{g} / \mathrm{L}$, however, as her IGF-I level on study day 2 was $14 \mu \mathrm{g} / \mathrm{L}$ she was included in the study. The study was approved by The Local Ethics Committee in Göteborg and the Swedish Medical Products Agency. All participants' parents gave written informed consent before start of study.

rhIGF-I/rhIGFBP-glucose preparation. Individual infusion solutions were prepared at the hospital pharmacy of the Queen Silvia Children's Hospital in the following manner. The study drug was mecasermin rinfabate (IPLEX, Insmed) that is an equimolar preparation of recombinant protein complex of rhIGF-I and rhIGFBP-3. IPLEX (Lots No. DP0506 and DP0609) vials were diluted with $10 \%$ glucose solution in two dilution steps to achieve the appropriate doses for each infant. The dilution of Iplex was done based on the individual study drug solution infusion rate, which was $1 \mathrm{~mL} / \mathrm{kg} / \mathrm{h}$ (i.e. 3 $\mathrm{mL} / \mathrm{kg}$ since infusion duration was standardized to $3 \mathrm{~h}$ ) in all infants. In both dilution steps, dilution bags (FREKA Mix; Fresenius Kabi AG) were used. Study drug and glucose solution were administered to the bags by different syringes. The solution was transferred to an infusion pump, Alaris Asena CC or IVAC P 7000 syringe pump (Alaris, Medical Systems, Hampshire, UK) which was connected to a syringe extension set (Product code: G30402C or G30303C) and filled with the infusion solution. The syringe and syringe extension set was filled with infusion solution and stored in refrigerator. After $3 \mathrm{~h}$, immediately before infusion, the set was flushed with the infusion solution before being connected to the pump. Thereafter, the set was attached to an umbilical catheter (Vygon UK Ltd, Art No. 1272.14: 2-lumen catheter in PUR) and the pump was set to administer the calculated dose. Serum samples for IGF-I and IGFBP-3 analyses were taken via a peripheral arterial line. The reason for choosing i.v. infusion was that s.c. injections in these infants was considered not possible due to their lack of s.c. fat. The manufacturing and purification of rhIGF-I/rhIGFBP-3 has earlier been described in detail (14).

Study protocol. On postnatal day 3 the rhIGF-I/rhIGFBP-3-glucose solution was infused over $3 \mathrm{~h}$. Serial blood samples $(0.1 \mathrm{~mL}$ at each time-point) for determination of serum IGF-I and IGFBP-3 were drawn: immediately before $(-3 \mathrm{~h})$, and after completion of infusion $(0 \mathrm{~h})$, and 1, 2, 6, 12, 18, 24, $48 \mathrm{~h}$, and $14 \mathrm{~d}$ after infusion.

The children's well being and vital signs were monitored as described below throughout the study. Glucose levels were measured on day of study drug administration: immediately before $(-3 \mathrm{~h})$ and after infusion were completed $(0 \mathrm{~h})$ and $1,12,24$, and $48 \mathrm{~h}$ after infusion. Serum samples for insulin measurements were taken immediately before infusion and at 1 and $24 \mathrm{~h}$ post infusion. Serum potassium $(\mathrm{K})$ and sodium $(\mathrm{Na})$ were measured at $0,1,2,3,4,5 \mathrm{~h}$, and $14 \mathrm{~d}$ after infusion. Heart rate and blood pressure were each measured before infusion, immediately after, and then each hour up to $12 \mathrm{~h}$. Weight measurements were performed daily from birth to study day eight.

Calculation of starting dose. For safety reasons, the starting dose in the first infant was the same as the mean amount of IGF-I that infants in a previous study had been given via routine plasma administrations. In this preceding pharmacokinetic study, 20 randomly selected preterm children (mean GA 25.3, SD 1.3 wk) received a transfusion of adult fresh frozen plasma (FFP), which contains IGF-I in various amounts) at a postnatal age of median (range) 2 (1-7) days. IGF-I was measured in the FFP and in the serum of the infants before, during, and after administration of FFP. The mean amount of IGF-I administered via FFP was $0.0014 \mathrm{mg} / \mathrm{kg}(1.4 \mu \mathrm{g} / \mathrm{kg} / 3 \mathrm{~h})$ (15). In the present study, to minimize the risk for adverse events, the first dose of rhIGF-I/rhIGFBP-3 was calculated from the "FFP results" and was decided to be $5 \mu \mathrm{g} / \mathrm{kg} / 3 \mathrm{~h}$ corresponding to $1.1 \mu \mathrm{g} / \mathrm{kg} / 3 \mathrm{~h}$ of rhIGF-I. Depending on the response, i.e. increase in serum IGF-I, the first infant or subsequent infants (in a longitudinal manner) either did not receive a second dose or received a second dose based on the response with the previous dose in the same or in the previous infant. The starting dose of rhIGF-I in the following infants was based on the response in the previous subject. The more the response deviated from the optimal target range $(20-25 \mu \mathrm{g} / \mathrm{L})$ at $24 \mathrm{~h}$ after infusion $\left(\mathrm{C}_{24}\right)$, the higher was the increase or decrease of the subsequent dose.

Analysis of IGF-I and IGFBP-3. Total IGF-I and IGFBP-3 serum concentrations were analyzed using IGFBP-blocked RIA and a specific RIA (Mediagnost GmbH, Tübingen, Germany). The IGF-I samples were diluted 1:50 and the IGFBP-3 samples were diluted 1:300. The intra-assay coefficients of variations (CV) for IGF-I were 18, 11, and $7 \%$ at concentrations of 9, 33, and $179 \mu \mathrm{g} / \mathrm{L}$, respectively. The intra-assay CV for IGFBP-3 was 10 , 7 , and $6 \%$ at concentrations of 716,1750 , and $3929 \mu \mathrm{g} / \mathrm{L}$, respectively. All samples were analyzed in the same assay. The methods have been described in detail previously (16).

Pharmacokinetic modeling. All serum concentrations of IGF-I and IGFBP-3 at baseline and up to $48 \mathrm{~h}$ after the stop of infusion of study drug were analyzed using nonlinear mixed effects modeling in NONMEM VI (17). An underlying endogenous level (baseline concentration) was estimated from the data and the pharmacokinetics of the infused IGF-I and IGFBP-3 were described by compartmental modeling. One- and two-compartment models with linear or nonlinear elimination were evaluated.

The choice of structural model, inclusion of between-subject variability in the parameters and the choice of additive or proportional residual error models were tested for statistical significance using the minimum objective function value (OFV) produced by NONMEM. A drop in OFV of 6.64, which corresponds to a significance level of $p<0.01$, was required for adding one extra parameter. Clearance (CL) and volume (V) terms were scaled allometrically by weight (18).

$$
\begin{gathered}
\mathrm{CL}=\mathrm{CL}_{1 \mathrm{~kg}} \cdot \text { weight }^{0.75} \\
V=V_{1 \mathrm{~kg}} \cdot \text { weight }
\end{gathered}
$$

Individual pharmacokinetic parameters of IGF-I and IGFBP-3 were derived using the POSTHOC step in NONMEM. The half-live was computed as $\mathrm{t}_{1 / 2}=\ln (2) \times \mathrm{V} / \mathrm{CL}$ and the area under the concentration-time curve (AUC) resulting from the mecasermin rinfabate infusion was computed as $\mathrm{AUC}=$ dose/CL.

Statistics. All data are expressed as the median and range. Predominantly descriptive statistics are presented. It was not appropriate to perform statistical hypothesis testing due to the small sample size.

\section{RESULTS}

Dose. Administration of rhIGF-I/rhIGFBP-3 had effects on serum concentrations of IGF-I and IGFBP-3 after the 

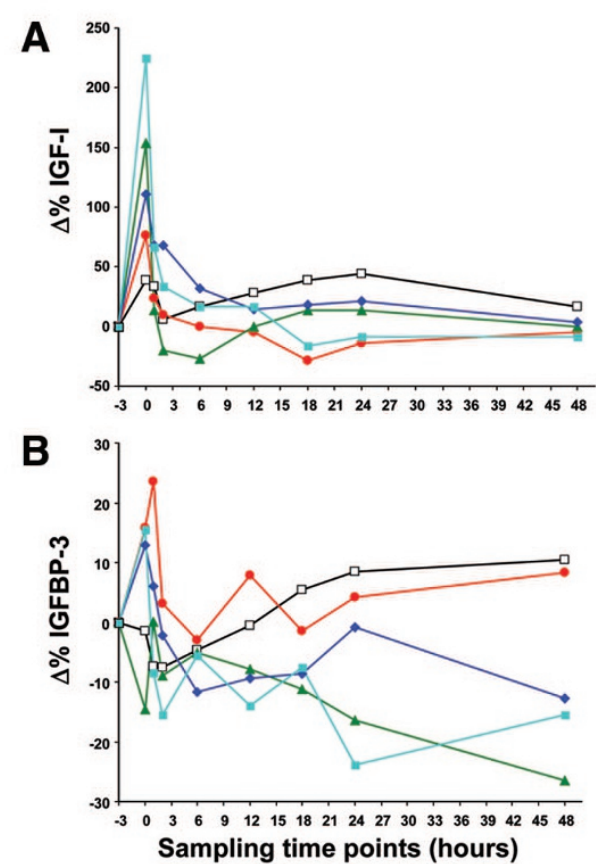

Figure 1. $A, \Delta \%$ IGF-I from baseline after $3 \mathrm{~h}$ infusion of IGF-I/IGFBP-3 in different doses $(n=5)$ in five study subjects. Sampling time points are immediately before study drug infusion $(-3)$, immediately following completed infusion of drug ( 0$)$, and at 1,2,6,12,18,24, and $48 \mathrm{~h}$ post completed drug infusion. One ( $880 \mathrm{~g} ; 6 \mu \mathrm{g} / \mathrm{kg})$; unfilled boxes and black line, $2(1,220$ $\mathrm{g} ; 24 \mu \mathrm{g} / \mathrm{kg}$ ); red filled circle and red line, 3 (760 g; $33 \mu \mathrm{g} / \mathrm{kg}$ ); green filled triangles and green line, $4(1,115 \mathrm{~g} ; 33 \mu \mathrm{g} / \mathrm{kg})$; dark blue rhomb and dark blue line, 5 (810 g; $59 \mu \mathrm{g} / \mathrm{kg})$; light blue filled boxes and light blue line. $B, \Delta \%$ IGFBP-3 from baseline after $3 \mathrm{~h}$ infusion of IGF-I/IGFBP-3 in different doses $(n=5)$ in five study subjects. Sampling time points are immediately before study drug infusion $(-3)$, immediately following completed infusion of drug (0), and at 1, 2, 6, 12, 18, 24, and $48 \mathrm{~h}$ post completed drug infusion. 1 (880 $\mathrm{g} ; 6 \mu \mathrm{g} / \mathrm{kg})$; unfilled boxes and black line, $2(1,220 \mathrm{~g} ; 24 \mu \mathrm{g} / \mathrm{kg})$; red filled circle and red line, $3(760 \mathrm{~g} ; 33 \mu \mathrm{g} / \mathrm{kg})$; green filled triangles and green line $4(1,115 \mathrm{~g} ; 33 \mu \mathrm{g} / \mathrm{kg})$; dark blue rhomb and dark blue line, 5 (810 g; 59 $\mu \mathrm{g} / \mathrm{kg}$ ); and light blue filled boxes and light blue line.

complex was administered to the infants at the postnatal age of $3 \mathrm{~d}$ during a 3 -h infusion. The individual percentage change from serum baseline concentrations of IGF-I and IGFBP-3 at the respective sampling time-points are shown in Fig. $1 A$ and $B$.

Median (range) IGF-I and IGFBP-3 levels immediately before infusion were 18 (12-28) and $771(651-1047) \mathrm{ng} / \mathrm{mL}$, respectively, Tables 2 and 3 . Immediately after completing the study, drug infusion $\left(C_{\max }\right)$ the observed median (range) serum IGF-I and IGFBP-3 levels were 38 (25-59) and 838 (658-1182) $\mathrm{ng} / \mathrm{mL}$, respectively. In all five children, the serum IGF-I levels, immediately after infusion, were within in utero range (13).

IGF-I and IGFBP-3 pharmacokinetic parameters. Onecompartment models with linear elimination were sufficient to describe the IGF-I data and the IGFBP-3 data. The endogenous serum baseline concentration, clearance $\left(\mathrm{CL}_{1 \mathrm{~kg}}\right)$, and distribution volume $\left(\mathrm{V}_{1 \mathrm{~kg}}\right)$ for IGF-I were estimated to 18.8 $\mu \mathrm{g} / \mathrm{L}, 0.0924 \mathrm{~L} / \mathrm{h} / \mathrm{kg}$, and $0.114 \mathrm{~L} / \mathrm{kg}$, respectively, with a calculated half-life $\left(\mathrm{t}_{1 / 2}\right)$ of $0.86 \mathrm{~h}$ for a typical child of $1000 \mathrm{~g}$, Table 2. The estimated between-subject variability (CV) in endogenous baseline concentration and CL were 34 and 31\%, respectively. The additive residual error was $2.56 \mu \mathrm{g} / \mathrm{L}$. The individual model-predicted maximum increase in IGF-I concentration from the estimated endogenous concentration after the mecasermin rinfabate administration was $19.5(3.4-28.3) \mathrm{ng} / \mathrm{mL}$ and AUC was computed to be $61.8(11.6-123) \mathrm{ng} / \mathrm{mL} \cdot \mathrm{h}$.

For IGFBP-3, the endogenous concentration, $\mathrm{CL}_{1 \mathrm{~kg}}$ and $\mathrm{V}_{1 \mathrm{~kg}}$ were estimated to $758 \mu \mathrm{g} / \mathrm{L}, 0.0698 \mathrm{~L} / \mathrm{h} / \mathrm{kg}$, and $0.0906 \mathrm{~L} / \mathrm{kg}$, respectively, resulting in a $\mathrm{t}_{1 / 2}$ of $0.90 \mathrm{~h}$, for a typical child of $1000 \mathrm{~g}$, Table 3. Between-subject variability in the estimated endogenous concentration of IGFBP-3 was $17 \%$ and the additive residual error was $60.4 \mu \mathrm{g} / \mathrm{L}$. The individual model-predicted maximum increase in IGFBP-3 concentration from the estimated endogenous concentration after the mecasermin rinfabate administration was $97.4(17.4-180.9) \mathrm{ng} / \mathrm{mL}$ and AUC was computed to be $351(61.2-636) \mathrm{ng} / \mathrm{mL} \cdot \mathrm{h}$.

All pharmacokinetic parameters are based on infant weight on day of study drug administration. Allometric scaling predicts that the increase in distribution volume is directly proportional to body weight whereas clearance is less than proportional to weight, resulting in that the typical half-life increases with body weight. The calculated typical half-life of IGF-I in an infant of $0.5 \mathrm{~kg}$ and $1.5 \mathrm{~kg}$ was $0.72 \mathrm{~h}$ and $0.95 \mathrm{~h}$, respectively, for IGF-1, and 0.76 , and $1.00 \mathrm{~h}$, respectively, for IGFBP-3.

Safety. There were no changes in blood pressure or heart rate that had clinical importance in any of the five patients, Fig. 2. Blood glucose levels after infusion were all normal.

Median (range) insulin concentrations in the five individuals were stable and normal immediately before, at $1 \mathrm{~h}$ or at $24 \mathrm{~h}$ after rhIGF-I/rhIGFBP-3 infusion and were 7.8 (6.6-17.0), 6.6 (1.719.0), and 8.4 (5.5-14.0) $\mathrm{mU} / \mathrm{L}$, respectively.

Serum sodium and potassium levels were within normal ranges at all measuring points. No difference was observed in

Table 2. Observed baseline, administered dose (based on weight at day of study drug infusion), maximum IGF-I concentration and

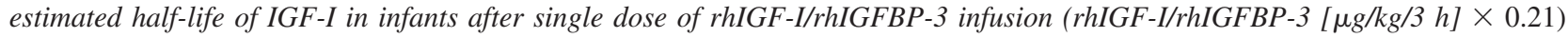

\begin{tabular}{|c|c|c|c|c|c|}
\hline $\begin{array}{l}\text { Characteristics } \\
\text { (gender) }\end{array}$ & $\begin{array}{l}\text { Baseline IGF-I } \\
(\mu \mathrm{g} / \mathrm{L})\end{array}$ & $\begin{array}{l}\text { Dose rhIGF-I/rhIGFBP-3 } \\
(\mu \mathrm{g} / \mathrm{kg} / 3 \mathrm{~h})\end{array}$ & $\begin{array}{l}\text { Dose rhIGF-I } \\
(\mu \mathrm{g} / \mathrm{kg} / 3 \mathrm{~h})\end{array}$ & $\begin{array}{l}\operatorname{Max} \text { IGF-I } \\
(\mu \mathrm{g} / \mathrm{L})\end{array}$ & $\mathrm{t}_{1 / 2}$ IGF-I (h) \\
\hline Girl & 18 & 6 & 1 & 25 & 0.785 \\
\hline Boy & 21 & 24 & 5 & 37 & 0.939 \\
\hline Boy & 15 & 33 & 7 & 38 & 0.701 \\
\hline Girl & 28 & 33 & 7 & 59 & 1.423 \\
\hline Girl & 12 & 59 & 12 & 39 & 0.593 \\
\hline
\end{tabular}


Table 3. Observed baseline, administered dose (based on weight at day of study drug infusion), maximum IGF-I concentration and estimated half-life of IGFBP-3 in infants after single dose of rhIGF-I/rhIGFBP-3 infusion (rhIGF-I/rhIGFBP-3 $[\mu \mathrm{g} / \mathrm{kg} / 3 \mathrm{~h}] \times 0.79)$

\begin{tabular}{|c|c|c|c|c|c|}
\hline $\begin{array}{l}\text { Characteristics } \\
\text { (gender) }\end{array}$ & $\begin{array}{l}\text { Baseline IGFBP-3 } \\
(\mu \mathrm{g} / \mathrm{L})\end{array}$ & $\begin{array}{l}\text { Dose rhIGF-I/rhIGFBP-3 } \\
(\mu \mathrm{g} / \mathrm{kg} / 3 \mathrm{~h})\end{array}$ & $\begin{array}{c}\text { Dose IGFBP-3 } \\
(\mu \mathrm{g} / \mathrm{kg} / 3 \mathrm{~h})\end{array}$ & $\begin{array}{l}\text { Max IGFBP-3 } \\
(\mu \mathrm{g} / \mathrm{L})\end{array}$ & $\mathrm{t}_{1 / 2} \operatorname{IGFBP}-3(\mathrm{~h})$ \\
\hline Girl & 864 & 6 & 3 & 851 & 0.871 \\
\hline Boy & 651 & 24 & 12 & 754 & 0.945 \\
\hline Boy & 771 & 33 & 16 & 658 & 0.839 \\
\hline Girl & 1,047 & 33 & 16 & 1,182 & 0.924 \\
\hline Girl & 726 & 59 & 26 & 838 & 0.853 \\
\hline
\end{tabular}

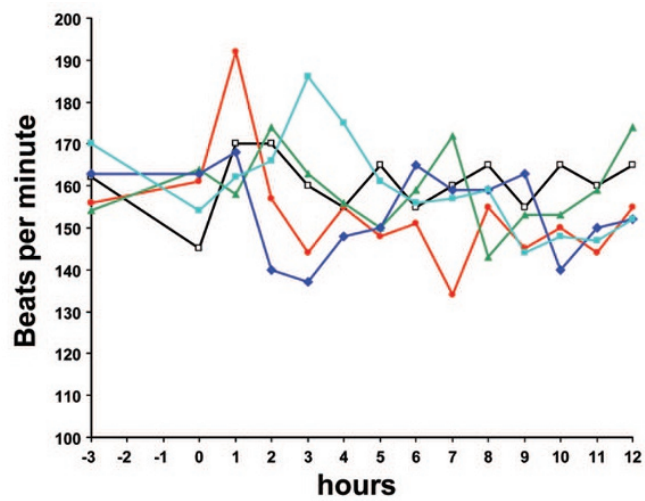

Figure 2. Heart rate (bpm) after $3 \mathrm{~h}$ infusion of IGF-I/IGFBP-3 in different doses $(n=5)$ in five study subjects. Sampling time points are immediately before study drug infusion $(-3)$, immediately following completed infusion of drug ( 0$)$ and thereafter at every hour up to $12 \mathrm{~h}$ post completed drug infusion. 1 ( $880 \mathrm{~g} ; 6 \mu \mathrm{g} / \mathrm{kg})$; unfilled boxes and black line, $2(1,220 \mathrm{~g} ; 24 \mu \mathrm{g} / \mathrm{kg})$; red filled circle and red line, $3(760 \mathrm{~g} ; 33 \mu \mathrm{g} / \mathrm{kg})$; green filled triangles and green line $4(1,115 \mathrm{~g} ; 33 \mu \mathrm{g} / \mathrm{kg})$; dark blue rhomb and dark blue line, $5(810 \mathrm{~g} ; 59 \mu \mathrm{g} / \mathrm{kg})$; and light blue filled boxes and light blue line.

i.v. glucose intake $(\mathrm{mg} / \mathrm{kg} / \mathrm{min})$ between the analyzed time periods, during the $6 \mathrm{~h}$ interval before rhIGF-I/rhIGFBP-3 infusion, during infusion and during the $6 \mathrm{~h}$ interval after infusion. Three, one, and one infant had the same (or higher) weight as on study drug administration after one, 2 and 3 days, respectively.

\section{DISCUSSION}

We found that i.v. infusion of an equimolar preparation of rhIGF-I/rhIGFBP-3 to very preterm infants can be effective in increasing serum IGF-I levels to the levels normally found in utero at the corresponding gestational age (14), and that administration of rhIGF-I/rhIGFBP-3 appears to be safe and well tolerated. A 3-h infusion resulted in a biologic half-life of the solution/complex of less than $1 \mathrm{~h}$.

Because IGF-I can bind to the insulin receptor and act like insulin there is a possibility of hypoglycemia with rhIGF-I/rhIGFBP-3 infusion. In the two youngest children, who had a history of low blood glucose levels before infusion, there was a slight drop of blood glucose, an hour after stopping the infusion, although the glucose level was normal. The normoglycemia observed throughout the study possibly reflects the co-infusion of $10 \%$ glucose (which is routine for extremely premature infants). Premature infants are also often insulin resistant (19), catabolic and have poor metabolic regulation. Several studies have shown that IGF-I may improve insulin sensitivity $(20,21)$ as well as have positive effects in children who are catabolic from severe burns $(22,23)$. IGF-I is an insulin sensitizer by virtue of its suppression of GH secretion, as well as through direct actions on peripheral tissues (24). Prematurity is a state of partial GH insensitivity that in part can explain the catabolic state of these infants. Elevated GH levels have earlier been shown to be more strongly associated with severe ROP than low levels of IGF-I (25). The complete role of the GH/IGF-I axis for retinopathy development is still not fully understood.

Main clinical indication in humans of recombinant human IGF-I alone (mecasermin) or as an equimolar preparation with rhIGFBP-3 (mecasermin rinfabate) to date, has been growth hormone insensitivity syndrome (GHIS/Laron syndrome) (26) and severe insulin resistance (27).

The mean half-life of $0.86 \mathrm{~h}$ for i.v. administered IGF-I in our study of premature infants is considerably shorter than in both older children and adults with GHIS as well as in healthy subjects in whom a half-life of free IGF-I after a $75 \mathrm{~min}$ constant i.v. infusion of rhIGF-I was calculated to be $14 \pm 1 \mathrm{~h}$ (28). Part of the explanation for the shorter half-life of the drug in the present study may be low endogenous levels of IGFBP-3 and ALS (29). The short half-life indicates that administration of IGF-I in preterm infants should be based on continuous infusion of IGF-I to achieve the targeted physiologic concentration.

IGF-I and IGFBP-3 levels both decrease after preterm birth and significant dips in endogenous IGF-I and IGFBP-3 levels at around 2-4 d after birth has recently been recognized (8). This decrease can confound the interpretation of IGFBP-3 levels seen after the 3-h infusion, as the amount of IGFBP-3 infused is not enough to "overcome" the physiologic decrease. This is more apparent with IGFBP-3 since the molar amount of IGFBP-3 infused with IPLEX is less, relative to endogenous IGFBP-3 levels, compared with the infusion of IGF-I. In addition, there is a possibility of degradation of nonglycosylated IGFBP-3 by proteases (nonglycosylated IGFBP-3 is more readily degraded than endogenous glycosylated IGFBP3 ), which might be explained by low ALS levels in these infants. 
In this very limited study on five patients with a narrow range of gestational ages and birth weight SDS, we did not see any correlation between these variables and response. We could only see that birth weight and baseline levels had an impact on the response. Predictions from the developed pharmacokinetic model suggest that in a preterm infant with a birth weight of $1000 \mathrm{~g}$ a dose of study drug between 100 and 150 $\mu \mathrm{g} / 24 \mathrm{~h}$, i.e. corresponding to $21-32 \mu \mathrm{g}$ of IGF-I, is required to increase the IGF- 1 concentrations by $10 \mathrm{ng} / \mathrm{mL}$ to achieve physiologic concentrations of IGF-I during the immediate postnatal period. This is a considerably lower dose than the s.c. dose approved by USFDA for children with severe primary IGF-I deficiency $0.12-2 \mathrm{mg} / \mathrm{kg}$ once daily $(1 \mathrm{mg}$ Mecasermin rinfabate equates to $0.2 \mathrm{mg}$ of rhIGF-I) (27). The results indicate that the predicted half-life of IGF-I and IGFBP-3 increases with increasing birth weight. This is because clearance is not directly proportional to weight whereas the distribution volume increases proportionally to weight.

The main reason for studying the pharmacokinetics of IGF-I in preterm infants is the implications this growth factor might have for the health of these infants. Postnatal low serum levels of IGF-I in preterm infants have been associated with poor growth, poor head circumference development and retinopathy of prematurity (12,30-34).

The main limitations of this study is that it would have been very interesting to measure factors like $\mathrm{GH}$ and IGFBP-I as this could have given us information about eliminating hypersomatotropinism and thus demonstrating adequate IGF-I replacement as well as insulin sensitivity. However, in these small infants the amount of blood that can be drawn is very limited and did not allow for these measures in the present study. This study does not provide a rationale for using the equimolar preparation of rhIGF-I/ rhIGFBP3 instead of IGF-I alone as an infusion in preterm infants.

In conclusion, we have shown for the first time that infusion of the equimolar preparation of rhIGF-I/rhIGFBP-3 elevates IGF-I in extremely preterm infants. The pharmacokinetic results serve as a basis for design of further studies on the efficacy and safety of the systemic use of IGF-I to improve growth, metabolic status as well as for neuro- and vasoprotection in extremely preterm infants.

Acknowledgments. We are indebted to Insmed Inc for the supply of rhIGF-I/rhIGFBP-3 and protocol assistance. We thank the staff at the Ophthalmology and Neonatal Unit Lena Kjellberg and Anne Rosenqvist, The Sahlgrenska Acadamy Hospital, Göteborg, for assistance and examination of patients and Gunnel Hellgren and Lisbeth Larsson for assistance in analyzing the IGF-I and IGFBP-3 samples.

\section{REFERENCES}

1. Gluckman PD 1995 Clinical review 68: the endocrine regulation of fetal growth in late gestation: the role of insulin-like growth factors. J Clin Endocrinol Metab 80:1047-1050
2. Hellstrom A, Perruzzi C, Ju M, Engstrom E, Hard AL, Liu JL, Albertsson-Wikland K, Carlsson B, Niklasson A, Sjodell L, LeRoith D, Senger DR, Smith LE 2001 Low IGF-I suppresses VEGF-survival signaling in retinal endothelial cells: direct correlation with clinical retinopathy of prematurity. Proc Natl Acad Sci U S A 98:58045808

3. Russo VC, Gluckman PD, Feldman EL, Werther GA 2005 The insulin-like growth factor system and its pleiotropic functions in brain. Endocr Rev 26:916943

4. Ye P, D'Ercole AJ 2006 Insulin-like growth factor actions during development of neural stem cells and progenitors in the central nervous system. J Neurosci Res 83:1-6

5. Hellstrom A, Engstrom E, Hard AL, Albertsson-Wikland K, Carlsson B, Niklasson A, Lofqvist C, Svensson E, Holm S, Ewald U, Holmstrom G, Smith LE 2003 Postnatal serum insulin-like growth factor I deficiency is associated with retinopathy of prematurity and other complications of premature birth. Pediatrics 112:1016-1020

6. Holly J, Perks C 2006 The role of insulin-like growth factor binding proteins. Neuroendocrinology 83:154-160

7. Lofqvist C, Chen J, Connor KM, Smith AC, Aderman CM, Liu N, Pintar JE, Ludwig T, Hellstrom A, Smith LE 2007 IGFBP3 suppresses retinopathy through suppression of oxygen-induced vessel loss and promotion of vascular regrowth. Proc Natl Acad Sci U S A 104:10589-10594

8. Hansen-Pupp I, Hellstrom-Westas L, Cilio CM, Andersson S, Fellman V, Ley D 2007 Inflammation at birth and the insulin-like growth factor system in very preterm infants. Acta Paediatr 96:830-836

9. Ashton IK, Zapf J, Einschenk I, MacKenzie IZ 1985 Insulin-like growth factors (IGF) 1 and 2 in human foetal plasma and relationship to gestational age and foetal size during midpregnancy. Acta Endocrinol (Copenh) 110:558-563

10. Lassarre C, Hardouin S, Daffos F, Forestier F, Frankenne F, Binoux M 1991 Serum insulin-like growth factors and insulin-like growth factor binding proteins in the human fetus. Relationships with growth in normal subjects and in subjects with intrauterine growth retardation. Pediatr Res 29:219-225

11. Engstrom E, Niklasson A, Wikland KA, Ewald U, Hellstrom A 2005 The role of maternal factors, postnatal nutrition, weight gain, and gender in regulation of serum IGF-I among preterm infants. Pediatr Res 57:605-610

12. Lofquist C, Engstrom E, Sigurdsson J, Hard AL, Niklasson A, Ewald U, Holmstrom G, Smith LE, Hellstrom A 2006 Postnatal head growth deficit among premature infants parallels retinopathy of prematurity and insulin-like growth factor-1 deficit. Pediatrics 117:1930-1938

13. Langford K, Nicolaides K, Miell JP 1998 Maternal and fetal insulin-like growth factors and their binding proteins in the second and third trimesters of human pregnancy. Hum Reprod 13:1389-1393

14. Camacho-Hubner C, Rose S, Preece MA, Sleevi M, Storr HL, Miraki-Moud F, Minuto F, Frystyk J, Rogol A, Allan G, Sommer A, Savage MO 2006 Pharmacokinetic studies of recombinant human insulin-like growth factor I (rhIGF-I)/rhIGFbinding protein- 3 complex administered to patients with growth harmone insensitivity syndrome. J Clin Endocrinol Metab 91:1246-1253

15. Hansen-Pupp I, Engstrom E, Niklasson A, Berg AC, Fellman V, Lofquist C, Hellstrom A, Ley D 2008 Fresh-frozen plasma as a source of exogenous insulin-like growth factor I in the extremely preterm infant. J Clin Endocrinol Metab 94:477482

16. Blum WF, Breier BH 1994 Radioimmunoassays for IGFs and IGFBPs. Growth Regul 4:11-19

17. Beal SL, Sheiner LB, Boeckmann AJ (eds) 1989-2006 NONMEM Users Guides. GloboMax, Inc., Ellicott City, MD

18. Anderson BJ, Holford NH 2008 Mechanism-based concepts of size and maturity in pharmacokinetics. Annu Rev Pharmacol Toxicol 48:303-332

19. Beardsall K, Ogilvy-Stuart AL, Frystyk J, Chen JW, Thompson M, Ahluwalia J, Ong KK, Dunger DB 2007 Early elective insulin therapy can reduce hyperglycemia and increase insulin-like growth factor-I levels in very low birth weight infants. J Pediatr 151:611-617; 617.e611

20. Clemmons DR, Moses AC, McKay MJ, Sommer A, Rosen DM, Ruckle J 2000 The combination of insulin-like growth factor I and insulin-like growth factorbinding protein-3 reduces insulin requirements in insulin-dependent type 1 diabetes: evidence for in vivo biological activity. J Clin Endocrinol Metab $85: 1518-1524$

21. Saukkonen T, Shojaee-Moradie F, Williams RM, Amin R, Yuen KC, Watts A, Acerini CL, Umpleby AM, Dunger DB 2006 Effects of recombinant human IGF-I/ IGF-binding protein-3 complex on glucose and glycerol metabolism in type 1 diabetes. Diabetes 55:2365-2370

22. Herndon DN, Ramzy PI, DebRoy MA, Zheng M, Ferrando AA, Chinkes DL, Barret JP, Wolfe RR, Wolf SE 1999 Muscle protein catabolism after severe burn: effects of IGF-1/IGFBP-3 treatment. Ann Surg 229:713-720; discussion 720722

23. Spies M, Wolf SE, Barrow RE, Jeschke MG, Herndon DN 2002 Modulation of types I and II acute phase reactants with insulin-like growth factor-1/binding protein-3 complex in severely burned children. Crit Care Med 30:83-88

24. Cohen P 2006 Overview of the IGF-I system. Horm Res 65:3-8

25. Hikino S, Ihara K, Yamamoto J, Takahata Y, Nakayama H, Kinukawa N, Narazaki Y, Hara T 2001 Physical growth and retinopathy in preterm infants: involvement of IGF-I and GH. Pediatr Res 50:732-736

26. Ranke MB 1996 Treatment of growth hormone insensitivity syndrome (GHIS) with insulin-like growth factor (IGF-I). Baillieres Clin Endocrinol Metab 10:401-410 
27. Williams RM, McDonald A, O'Savage M, Dunger DB 2008 Mecasermin rinfabate: rhIGF-I/rhIGFBP-3 complex: iPLEX. Expert Opin Drug Metab Toxicol 4:311-324

28. Frystyk J, Hussain M, Skjaerbaek C, Porksen N, Froesch ER, Orskov H 1999 The pharmacokinetics of free insulin-like growth factor-I in healthy subjects. Growth Horm IGF Res 9:150-156

29. Mizuno N, Kato Y, Iwamoto M, Urae A, Amamoto T, Niwa T, Sugiyama Y 2001 Kinetic analysis of the disposition of insulin-like growth factor 1 in healthy volunteers. Pharm Res 18:1203-1209

30. Kajantie E 2003 Insulin-like growth factor (IGF)-I, IGF binding protein (IGFBP)-3, phosphoisoforms of IGFBP-1 and postnatal growth in very-low-birth-weight infants. Horm Res 60:124-130
31. Lofqvist C, Andersson E, Sigurdsson J, Engstrom E, Hard AL, Niklasson A, Smith LE, Hellstrom A 2006 Longitudinal postnatal weight and insulin-like growth factor I measurements in the prediction of retinopathy of prematurity. Arch Ophthalmol 124:1711-1718

32. Smith LE, Kopchick JJ, Chen W, Knapp J, Kinose F, Daley D, Foley E, Smith RG Schaeffer JM 1997 Essential role of growth hormone in ischemia-induced retinal neovascularization. Science 276:1706-1709

33. Smith LE, Shen W, Perruzzi C, Soker S, Kinose F, Xu X, Robinson G, Driver S, Bischoff J, Zhang B, Schaeffer JM, Senger DR 1999 Regulation of vascular endothelial growth factor-dependent retinal neovascularization by insulin-like growth factor-1 receptor. Nat Med 5:1390-1395

34. Villegas Becerril E, Gonzalez Fernandez R, Fernandez Molina F, Gallardo Galera JM 2005 Growth factor levels and ROP. Ophthalmology 112:2238 